\title{
Increasing and Sustaining Agricultural Productivity through Land Improvement Approach: A Mitigation Measure to Climate Change
}

\begin{abstract}
Due to greenhouse gas effect temperature around the world will increase $\left(0.06^{\circ} \mathrm{C} / \mathrm{yr}\right.$. $)$ resulting in increased evapo-transpiration and increased need of crop irrigation pressurizing ground water resources and its judicious use. An experiment in a deep tubewell area with improved land and irrigation management undertaken in early 1980's has shown that doubling of agricultural productivity is possible. This system can be taken as mitigative/adaptive measure of climate change.

This paper involves experiences of managing tubewell irrigation schemes through improving basically these development parameters in the irrigation command area:

- Land improvement (land consolidation, rectangular shaping and leveling),

- Irrigation canal efficiency improvement,

- Introduction of crop water management, and

- Evolving Farmers Group into a Co-operative Organization- for managing land collectively.

The evaluation has shown that through this intervention approach yields of paddy, wheat, maize and pulse can be doubled in the irrigated areas. This concept might be useful to modify the present policy and program vision of irrigated agriculture development in Nepal through enhancing water productivity a mitigation measure of the effects of climate change. Also, this approach is applicable to surface irrigation schemes of Terai and hills of Nepal.
\end{abstract}

Key words: Land rectangulation and consolidation, irrigation, agriculture, Nepal

\section{Background}

Q cientists all over the world are of the opinion that Dthere will be change in the earth temperature at a rate of $0.06^{\circ} \mathrm{C} / \mathrm{yr}$ in high carbon emission level (NASA 2010) due to which there would be dryer dry season and wetter rainy season. Some area would be affected by drought while other areas by heavy floods. There might be significant impact on the hydrological cycle affecting rainfall patterns, intensity and amounts. Researchers have forecast that $70 \%$ of the snow and glaciers might vanish due to a $4^{\circ} \mathrm{C}$ rise in the temperature. This increasing temperature and water stress are expected to lead to a 30\% decrease in crop yields in Central and South Asia by the mid 21st century (Chattopadhyay 2008).

Most of the big rivers in Nepal originate from snowy mountains and recharge the groundwater resource. If such river flow decreases and rainfall amounts and distribution change, there could be greater depletion of groundwater resource, due to increase in evapotranspiration and pressing needs of more and more. In such a situation, as a mitigation measure, a wise thing would be to use groundwater resource judiciously adopting land improvement measures experimented on by the Department of Agriculture in Nepal, as explained in this paper.

Land development works carried out in many countries show positive impacts on increasing productivity, efficient use of irrigation and substantial change in economy.

Forty years experience of land consolidation in Morocco (Essadiki 2005) guarantee better productivity, stability of rural population, the creation of job for rural people and development of economy. Similar success stories of land consolidation in irrigation project are reported from Kosovo (Meha and Kadiri 2005).

To meet the food requirements of the growing population of Nepal in future, it would be very hard or almost impossible to increase the land productivity due to following threats if some right steps on land management and irrigation practices are not initiated:

- Young people migration to foreign country for job might remarkably decrease agricultural labor force in hills and Terai lowlands of Nepal (youths from almost half of the households have already migrated).

- Traditional practices of land fragmentation are limiting the adoption of mechanization. Land fragmentation increases the field channels length and there by increases field water losses while irrigating.

- Global warming and temperature changes are alarming hydrological cycles changes affecting crop yields.

During 1983-1984, the then Farm Irrigation and Water Utilization Division (FIWUD) under Department of Agriculture (DOA) of Nepal decided to experiment on a small land development program in tubewell number 5 of Chainpur village, Parsa District in Nepal's Terai region. The program included key parameters of land improvement such as land leveling, shaping, consolidating; parameters of irrigation such as reduction of cost of irrigation, improving irrigation efficiency, and canal lining; and parameters of agriculture such as motivating users for increased dose of Nitrogen, Phosphorus and Potash (NPK) fertilizer use. After intervention of the program, the results and impacts were evaluated after one year, during February 1985.

The tubewell was installed in 1970 by the Parwanipur Canal Division under a minor irrigation scheme. The original maximum designed discharge of the $360 \mathrm{ft}$ deep tubewell with $30 \mathrm{~cm}$ casing pipe was 42 liter per 
second $(\mathrm{l} / \mathrm{sec})$. But the pump was very old and mechanically inefficient and, therefore, its discharge decreased to $30.58 \mathrm{l} / \mathrm{s}$. The target command area of the tubewell was 50 hectares. The existing observed situations of project performance were as listed below:

- Farmers used to receive water from pump house through brick lined and earthen channel and distributed by means of plot to plot irrigation.

- The duration of irrigation of one hectare of land was more than 27 hours with the available stream size of $10 \mathrm{l} / \mathrm{s}$ available to lowest farmers.

- A majority of the farmers (48\%) irrigated their fields through a plot to plot method; only $22 \%$ farmers had direct access to masonry brick-lined canal, and thus 30\% of the total land remained fallow during winter and summer seasons. Most of the irrigation plots were undulating needing longer time for irrigation (See Figure 1).

- The farmers used to completely irrigate their paddy fields during the rainy season only (JuneSeptember).

- Each farmer, irrespective of the location of his plot, had to pay the same rate per pumping hour.

- There were unhealthy wheat plant growths within the field. Also, tail end farmers did not grow wheat at all as the upstream plot farmers did not allow water through their land.

- The overall impact of inequity in the volume of water received, and limited access of users over irrigation water, resulted in low average agricultural yield: paddy $2,010 \mathrm{~kg} / \mathrm{ha}$, wheat $2,225 \mathrm{~kg} / \mathrm{ha}$, maize 1,492 $\mathrm{kg} / \mathrm{ha}$ and pulse $800 \mathrm{~kg} / \mathrm{ha}$.

After a detailed investigation of the above constraints to better agricultural productivity, FIWUD decided to experiment with a land improvement program that consisted of four main components: land improvement, irrigation efficiency improvement, crop and water management technology, and establishment of farmers co-operative.

The project ended without completion of the last component as land revenue department and land survey division did not support issuing new land ownership certificates to farmers. Also, the then existing land management policy did not foresee the benefits of land improvement.

However, the concept, strategy and approach adopted then are very useful, replicable and results oriented to current policy and programs of the government of Nepal.

The goal and objectives of the program were as following:

\section{Goal}

The expected goal of the land development works was to increase the productivity of paddy, wheat, maize and pulse through land management approach.

\section{Objectives}

The following objectives were set to achieve above goal:

- Land Leveling - for uniform spread of water front over the land, for shortening the total time taken to cover the land, and to maintain uniform water infiltration rate over the plot,

- Land Shaping - for domestic mechanization (use of medium machinery), for direct access to irrigation canals, and for maintaining equitable water distribution to each plot,

- Land Consolidation - for close crop supervision, application of farm machinery collectively decreasing the agricultural labor and machinery movement time of the farmers. The scattered plots of land in several places belonging to one farmer are proposed to be made (consolidated) in one place by exchange of land with other farmers,

- Improving Irrigation Channel - for higher efficiency of water delivery, and

- Evolving Farmers Group into a Co-operative Organization - for managing production and land collectively.

\section{Methodology and Approach}

The following approaches were followed to accomplish the land improvement activities.

\section{Expression of interest (EOI) collection}

Intention and interest gathering meeting - For this, a farmer's meeting was held in the field under a tree. The 
field team explained the land productivity constraints in the tubewell area for higher productivity. It also explained the process of land improvement along with the five basic parameters mentioned in the objectives heading.

EOI and application collection - All interested farmers applied with land details to FIWUD office for land improvement. A total of 21 hectares of land was included as pilot effort for land improvement.

Registration - A register of farmers' original plot number was prepared from cadastral map and land ownership certificate.

\section{Field activities for land potting, leveling and consolidation \\ Survey}

A plane table survey was carried out at the beginning for verifying the existing land area to that of land ownership certificate and for first hand land records. A contour survey was carried out at $5 \mathrm{~m} \times 5 \mathrm{~m}$ grid point to lay drainage canals, irrigation canal, plot design and to determine cut and fill.

\section{Target Field Characteristics}

After discussion with the farmers the following field characteristics were agreed upon and implemented by both agency staff and beneficiary farmers:

Field plot size - Plots size of $40 \mathrm{~m} \times 6 \mathrm{om}$ (about 1/4 ha or 7.01 kattha or 4.72 ropani) were developed.

Plot levelness - Each plot was leveled to $3 \mathrm{~cm}$ level difference within the plot.

Field shape - All plots were made rectangular except those located at corners.

Field boundary - Original field boundary was demolished and a new boundary bund of 8"x8" was laid straight and uniform around the plot.

Water inlet position on the field boundary - It was fixed almost in the center of the plot.

Farmers having smaller size scattered land Farmers having lands in different locations were grouped together for collective farming.

Equipment and material used - Local labors were used for demolishing field boundary. Tractor drawn scrapper and skilled labors were used for field leveling. Farmers were advised to level their field after each crop season at least for two times.

\section{Plot Distribution}

The scattered plots of one farmer in several places were rearranged in one place. Land plots of many farmers were pooled for making rectangle and consolidation; then the ownership was rearranged.

After completion of field leveling, plotting and consolidation work, each farmer was allotted his improved plot area equal to that of the area written in the original land certificate and almost close to original location. For this, a new land area survey (for new plots and numbers) was completed through plane table survey.

\section{Subsidy Provision}

The farmers were provided with half of the recommended dose of fertilizer freely for one season to compensate for the anticipated yield loss resulting from top soil disturbances and potential yield loss.

\section{Physical Facilities}

Each plot was connected in one side to $5 "$ thick brick lined canal, having flush point with 1:3 cement mortar and having $0.3 \mathrm{~m}$ bed width and $0.30 \mathrm{~m}$ wall height resulting into a channel density of $90 \mathrm{~m} / \mathrm{ha}$. Also each plot was connected to earthen drainage trapezoidal in shape $0.3 \mathrm{~m}$ bed width and $0.6 \mathrm{~m}$ height with 1:1 side slope. In this way the drainage density came to be $82 \mathrm{~m} / \mathrm{ha}$.

\section{Data Collection Methods for Evaluation}

Flow measurement - For this cut throat flume (4" x 3") size was used.

Soil moisture deficit (SMD) - Soil samples from 6" depth were taken by auger hole, SMD was evaluated through appearance relationship chart.

Flow advance - Advance time was measured by making equal distance along the field and using stop watch.

Field levelness - It was measured with precision level instrument at $5 \mathrm{~m}$ grid spread.

Infiltration - Inner and outer ring infiltrometers were used at locations $5 \mathrm{~m}$ away from the boarder.

Crop density - Standing wheat plants per square meter were counted from the randomly selected plots.

Cropping intensity - Past records and present observation were analyzed.

Nutrient content in soil - Three samples from each plot were taken and analyzed by means of soil test kit.

Yield data - Household interviews were conducted in each season using census survey method.

\section{Results and Achievement}

The following results and improvements/changes were observed and recorded after one year of experiment. This evaluation study was conducted during winter season covering all crops of previous year.

\section{Improvement on Agronomical Parameters Agricultural yield increment}

As a result of land improvement and efficient irrigation practice paddy, wheat, maize and pulse yield doubled in the experiment area. This yield increase can be attributed to uniform distribution of fertilizer over entire plot, less time required for irrigation, adoption of high yielding variety, adequate and timely water availability. A comparative picture of agricultural yield before and after the land improvement can be seen in the following table. 


\begin{tabular}{|r|c|c|c|}
\hline Crop & $\begin{array}{c}\text { Before Land } \\
\text { Improvement } \\
\mathbf{~ k g} / \mathbf{h a}\end{array}$ & $\begin{array}{c}\text { After Land } \\
\text { Improvement } \\
\mathbf{~ k g} / \mathbf{h a}\end{array}$ & $\begin{array}{c}\text { Increment } \\
\%\end{array}$ \\
\hline Paddy & 2,010 & 4,300 & 213 \\
Wheat & 2,225 & 4,620 & 207 \\
Maize & 1,492 & 5,400 & 262 \\
Pulse & 800 & 1,800 & 225 \\
\hline
\end{tabular}

Table 1. Improvement in Farm Productivity (from Household Survey).

\section{Cropping intensity increment}

It was recorded that cropping intensity before Land Improvement Project (LIP) limited to $190 \%$ due to unavailability of irrigation water to tail end farmers. Field irrigation by tubewell water also became costlier to farmers, as there occurred heavy water loss (up to 82\%) while following field to field irrigation. Due to inadequacy of water, farmers often left their land fallow. When direct access of water was provided to each land improvement (LI) plot, there were added incentives of adequate and timely irrigation availability to farmers. This direct access to irrigation water caused raised

cropping intensity up to $279 \%$ (paddy, wheat and pulse).

\section{Plant Density}

After land improvement, farmers' attitudes for higher crop yield appeared supportive; hence, they applied the recommended dose of NPK fertilizer. This resulted higher number (360-476) of plants per square meter, whereas on unimproved land area it ranged from 156-192 only, with low dose of NPK use.

\section{Improvement over Land Parameters Land leveling}

As a result of land leveling, surface characteristics of the fields were changed resulting into direct effects on water front movement and time needed to irrigate particular fields.

In Land Improved Area (LIA) plots, 90\% of the leveled plots could achieve a $3 \mathrm{~cm}$ difference in levels and $10 \%$ field could achieve a $5 \mathrm{~cm}$ level difference; whereas a level difference of $13 \mathrm{~cm}$ was observed in $86.66 \%$ of the total fields on unimproved lands (see Figure 2).
The following advantages were observed on uniform leveled plot after land improvement:

- There was uniform surface water front movement in the LIA plots. The front covered the soil from left corner to right corner of the fields (see Figure 3).

- Farmers could apply a standard uniform depth of $8.36 \mathrm{~cm}$ of water while irrigating the wheat all over the LIA plots whereas irrigation depth up to 11.63 $\mathrm{cm}$ was applied during wheat season in Unimproved Land Area (ULA) plots, wasting considerable amount of water.

- A shorter duration (8.52-8.86 hrs/ha) of irrigation time was observed in LIA plots against the irrigation duration taken $22.17 \mathrm{hrs} /$ ha in ULA plots. This short duration of irrigation application saved considerable amount of tubewell irrigation service fee. Time saved was four hours or equivalent to NRs. 64.00/ha. Diesel fuel saved was NRs. 12.00/l/ha or NRs. 85.0o/ha.

- There was considerable improvement in soil infiltration also in LIA plots. Water infiltrated upto 6 $\mathrm{cm}$ deep in the same soil against $2.4 \mathrm{~cm}$ depth in ULA plots for the same duration of application.

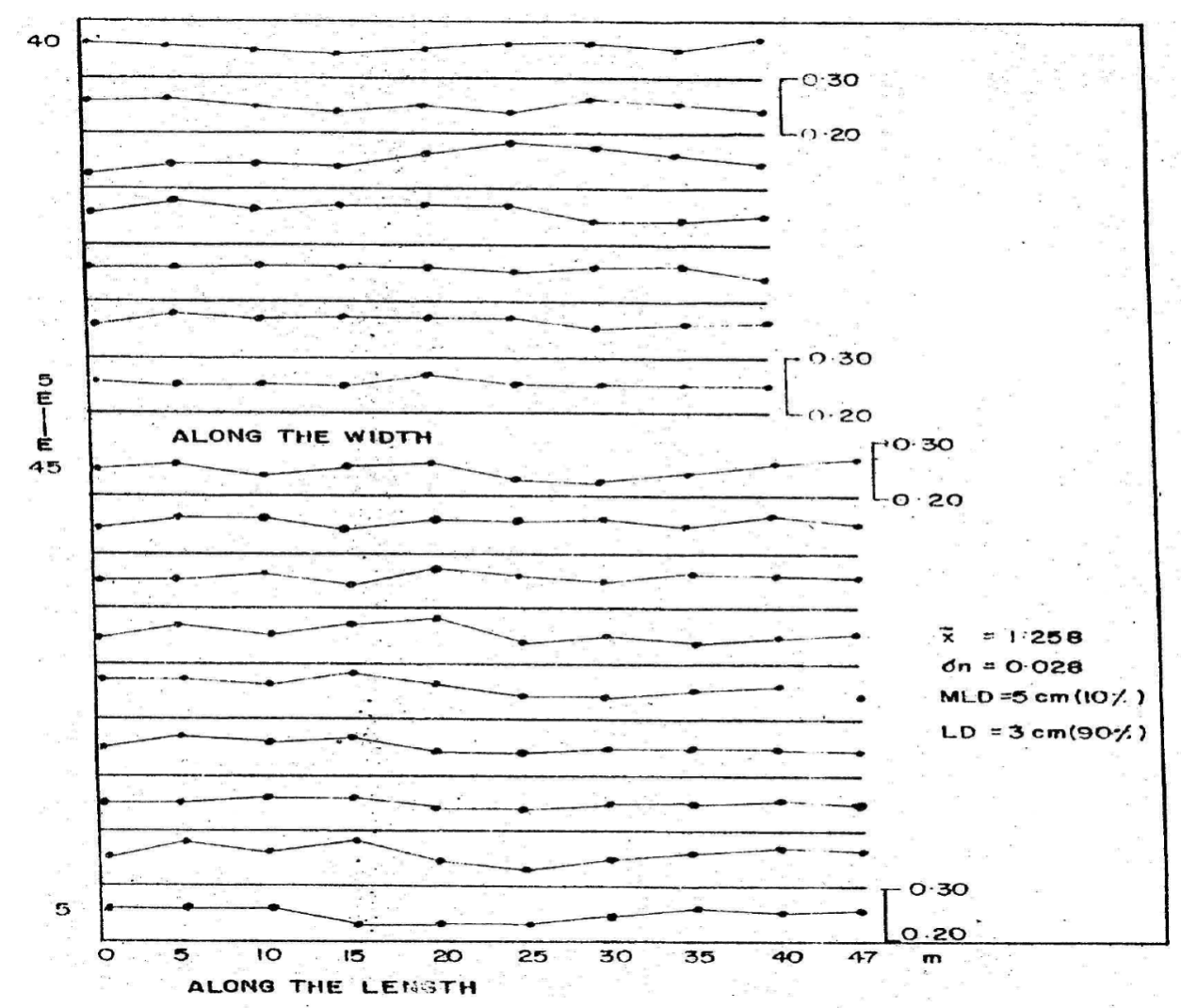

Figure 2. Leveled Plot (Plot of Farmer Rameshower Mahato).

\section{Land shaping}

After pooling land from individual farmers, the original shapes were changed into a standard shape of $40 \mathrm{~m}$ by $60 \mathrm{~m}$ area equal to one-fourth of a hectare (see Figure 4). The land shaping action facilitated further activities of irrigation and agriculture as following:

- All plots under LIA had direct access to irrigation 
canals and drainage ditch. Before land improvement only $22 \%$ of the total plots had direct access to irrigation canals.

- The duration of irrigation per unit area shortened by almost half after land improvement.

\section{Land consolidation}

- After land consolidation farmers were able to supervise their crops just standing in one corner of the field. It saved considerable labor and equipment movement time and cost of the farmers.

$M$

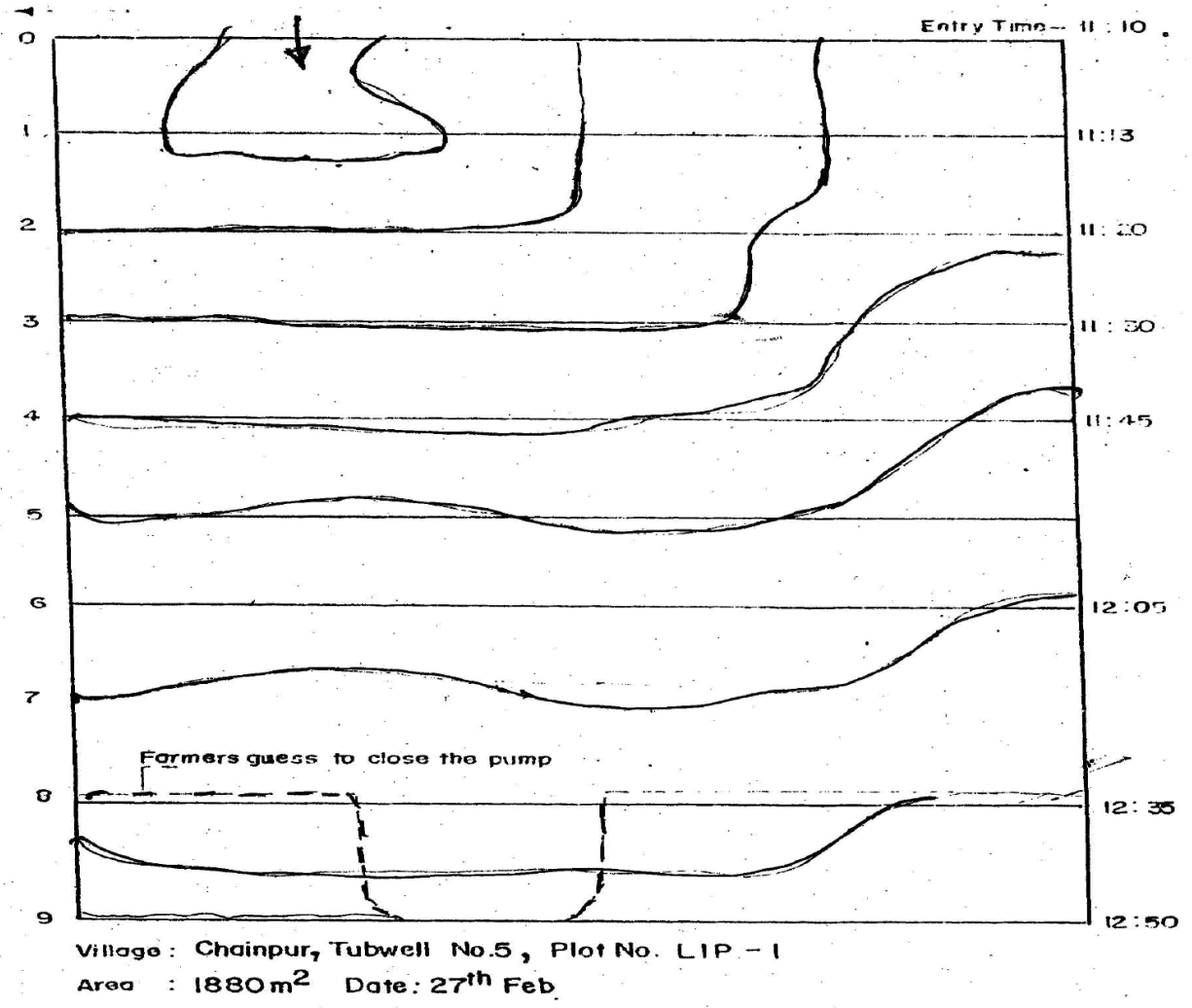

Figure 3. Water Front.

- Cost of tubewell irrigation charge was decreased as there was decrease in overall duration of irrigation for the same area.

- Even though, there is a legal provision for land pooling project for housing purposes in Nepal; there is no such legal provision for agricultural purposes.

\section{Improvement over Irrigation Parameters}

The synergetic effects of land leveling, land shaping, land consolidation and canallining impacted considerably such irrigation parameters as efficiency, application and duration. The impacts were quite visible:

- Farmers applied more depth $11.81 \mathrm{~cm} \mathrm{(269 \%} \mathrm{more}$ than the required depth $3.2 \mathrm{~cm}$ of irrigation obtained as soil moisture deficit) of water than the applied depth $8.36 \mathrm{~cm}$ (160\% even more than required) of water in the LIA plots. Thus, 109\% of total depth of application was saved against the potential saving of $269 \%$ of depth of application by land development.
- The overall conveyance efficiency (brick canal $80.48 \%$, earthen channel $68 \%$, plot to plot irrigation 49.34\% just irrigating from one upper plot to lower plot) was improved from $27 \%$ to $97 \%$ (making direct access to brick canal) (see Figure 5 ,a sample flow hydrograph is presented).

- In order to minimize the loses of expensive tubewell water the efficiency of the brick lined channel was improved from $80 \%$ to $97 \%$ by cement plastering (1:3 cement mortar) the inner face of the brick lined canals after evaluation of the canal efficiency. Likewise the efficiency of the small six year old and normally covered with sods earthen canal having bed width 30 $\mathrm{cm}$ and bank height $45 \mathrm{~cm}$ channel was measured to $65.58 \%$.

\section{Conclusions}

To summarize, keeping present national issues like agricultural labor movement to foreign countries, there is a need for more agricultural production to meet the food requirements of the growing population and to counteract the wastage of considerable irrigation water. The time has come to step into mechanized collective farming with land and irrigation development activities as tried in the case study about the tubewell command system.

The following conclusions come after completion and analysis of the data:

- Existing agricultural productivity can be doubled through scientific approach of land levelling, shaping, consolidation and crop water management technology.

- Uniformity in land productivity can be achieved and maintained within the individual plot through land levelling which results in uniform water movement over the field, decreases irrigation timing and maintains uniform water application depth.

- Application of farm mechanization, direct access of irrigation water to plots (for equitable benefit sharing), direct disposal of excess water in the drain is possible only through land shaping to appropriate dimension.

- Farmers' labor saving, intensive crop cultivation, promotion of collective farming is possible through land consolidation. 


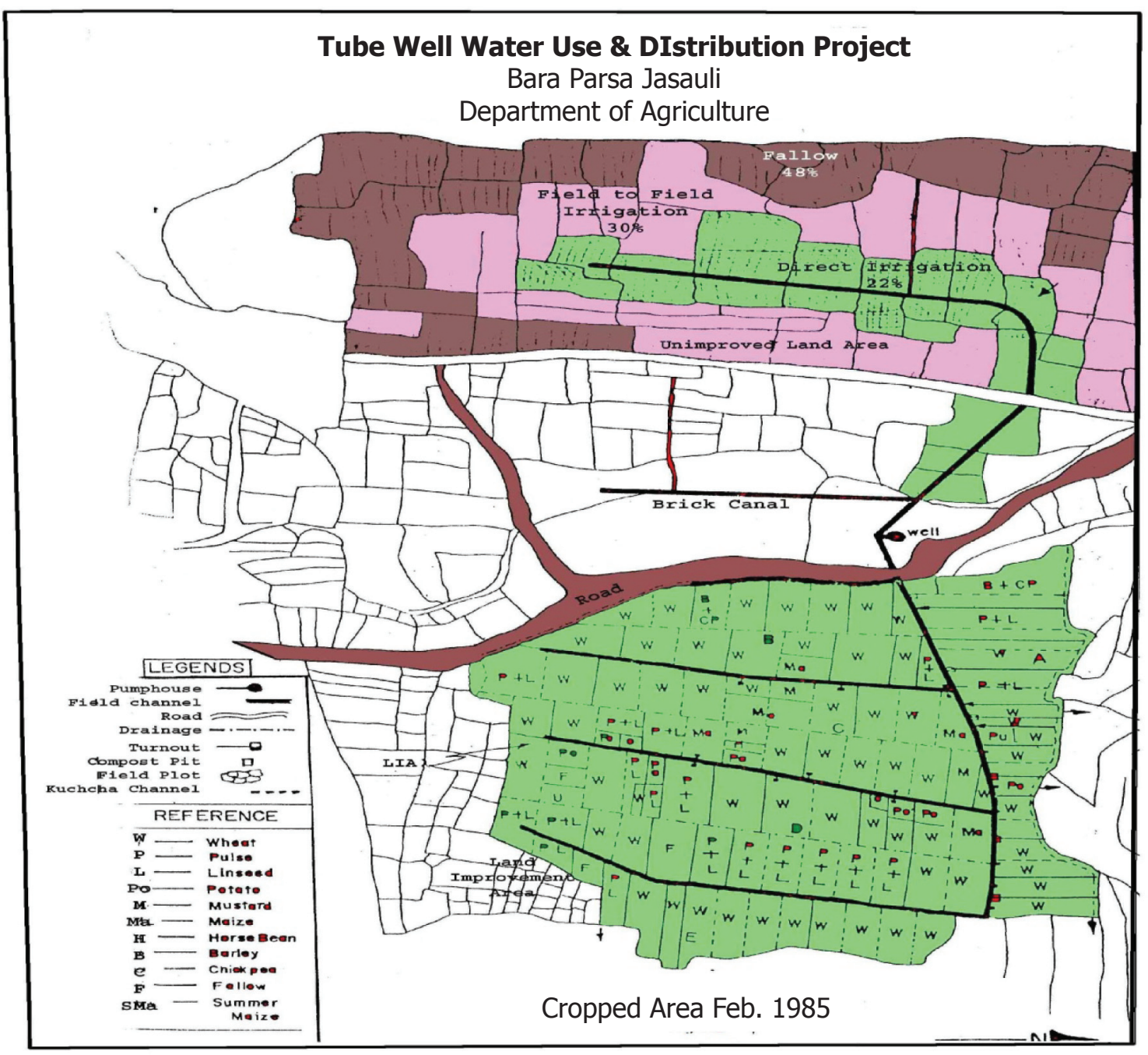

Figure 4. After Land Leveling.

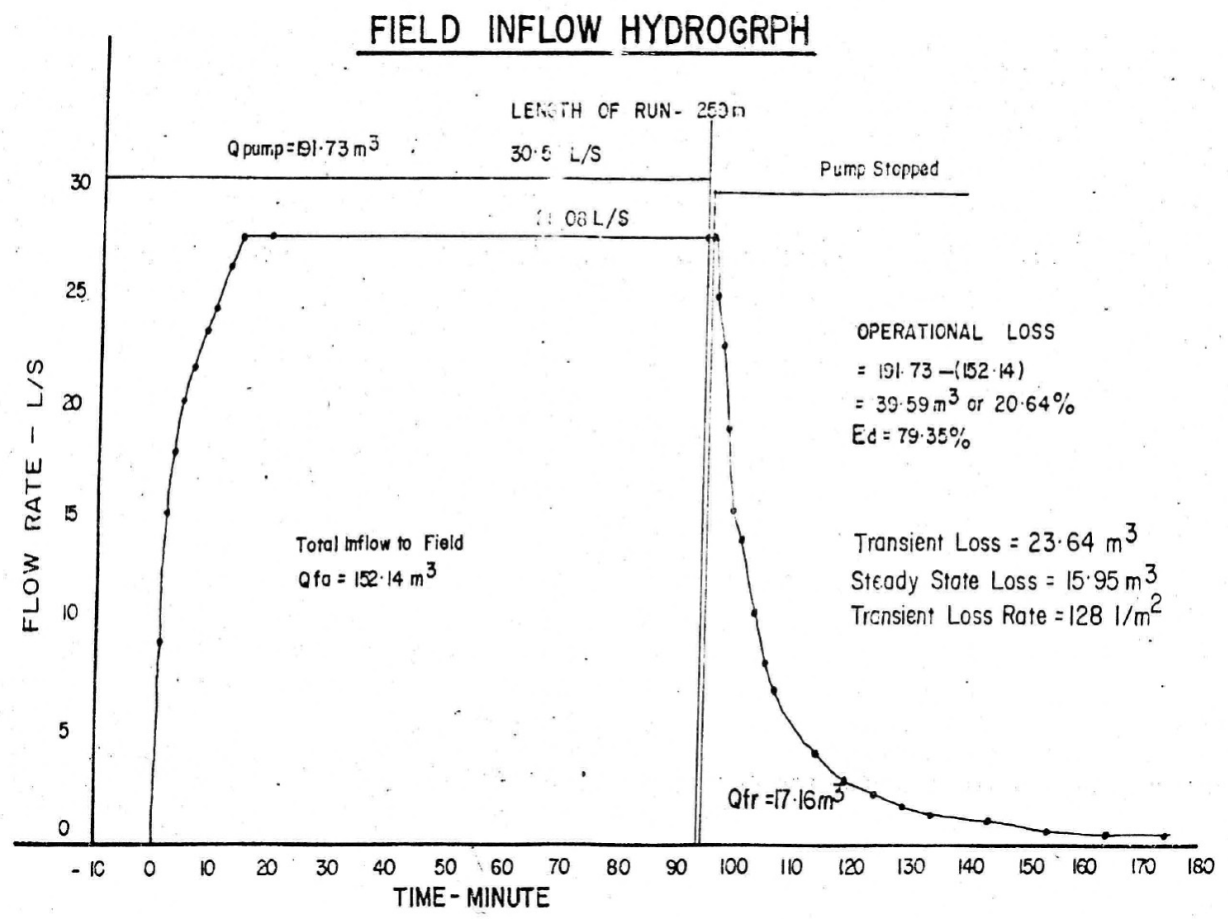

Figure 5. Flow Hydrograph. 
- Considerable quantity of irrigation water can be saved through simultaneous efforts applied in land improvement, and canal improvement. There is wide opportunity of area extensions for irrigation with the saved water.

- Sustainability of the benefits derived out of land and irrigation development might be possible through establishment of production and service co-operative in the area.

\section{Recommendations}

Nepal should initiate the following:

- Review and modify the old Land Reform Act to accommodate land consolidation and irrigation management, so that agricultural mechanization can be adopted, whereby small numbers of farmers can operate and manage big land holdings.

- Land improvement tasks should be initiated in all irrigation schemes (tubewell and surface irrigation schemes) giving first priority to the terai lowlands and hill areas particularly designated (by law) as agriculture zones.

- Adequate legal provisions should be made supportive of allowing land ownership change, field boundary demolition, subsidy against top soil loss, standardization of field plots and irrigation network density, and prohibition to further land fragmentation are necessary.

R. R. S. Neupane, Master of Engineering (ME), is an Irrigation Water Management Specialist with
35 years working experience in different projects of Nepal government as government officer and in other management transfer projects financed by ADB, USAID and the World Bank, as Team Leader or Deputy Chief of Party. At present, he is working as Deputy Team Leader in Consultant Team employed by SHELADIA-Multi $\mathrm{J} / \mathrm{V}$ in Irrigation Water Resource Management Project (IWRMP) financed by WB/DOI.

Corresponding address: samirne@enet.com.np

\section{References}

Chattopadhyay, N., 2008, 'Climate change and food security in India'. URL: www.wamis.org/agm/ meetings/rsamao8/S402-Chattopadhyay-Climatechange_Food-Security.pdf

Essadiki, M., 2005, 'Land consolidation in Morocco : Situation and Perspective'. URL: www.fig.net/pub/ cairo/papers.

Meha, M. and Q. Kadiri, 2005, Kosovo case study. Land consolidation in the creation of a cadastral model and its influence in the economic development of Kosovo. URL: $\quad$ www.fao.org/fileadmin/user_upload/.../ Land2005/Kosovo.pdf

NASA, 2010, 'Global Warming Feature Article- earth Observatory'. URL: earthobservatory.nasa.gov/ Features/GlobalWarming/

Priyadarsini, N., 2007, 'Impact of global warming and climate change on groundwater'. URL: network. earthday.net/profiles/blogs/impact-of-globalwarming-and.

WaterAID, 2007 , 'Climate change and water resources'. URL: $\quad$ www.wateraid.org/documents/climate_ change_and_water_resources_1.pdf.

\section{Nepal Hydropower Association (NHA) Elects Executive Committee}

The AGM of NHA held its 12th AGM on 20 January 2012. On this day, Executive Committee (EC) members were elected for a two year term. Er. Kiran Malla is elected President, Dr. Meg B. Bishwakarma is Vice president, Er. Bhanu Pokharel is General Secretary, and Er. Arun Rajauria is Treasurer. The other members are Er. Mohan R. Shakya, Er. Madhusudhan Adhikari, Er. Bikash Kumar Agrawal, Er. Vishnu Bahadur Singh, Er.ani Dahal, Dr. Hari Prasad Neupane, and Mr. Bharat Raj Pant. HYDRO Nepal journal wishes the $\mathrm{EC}$ members for a successful tenure in the NHA.

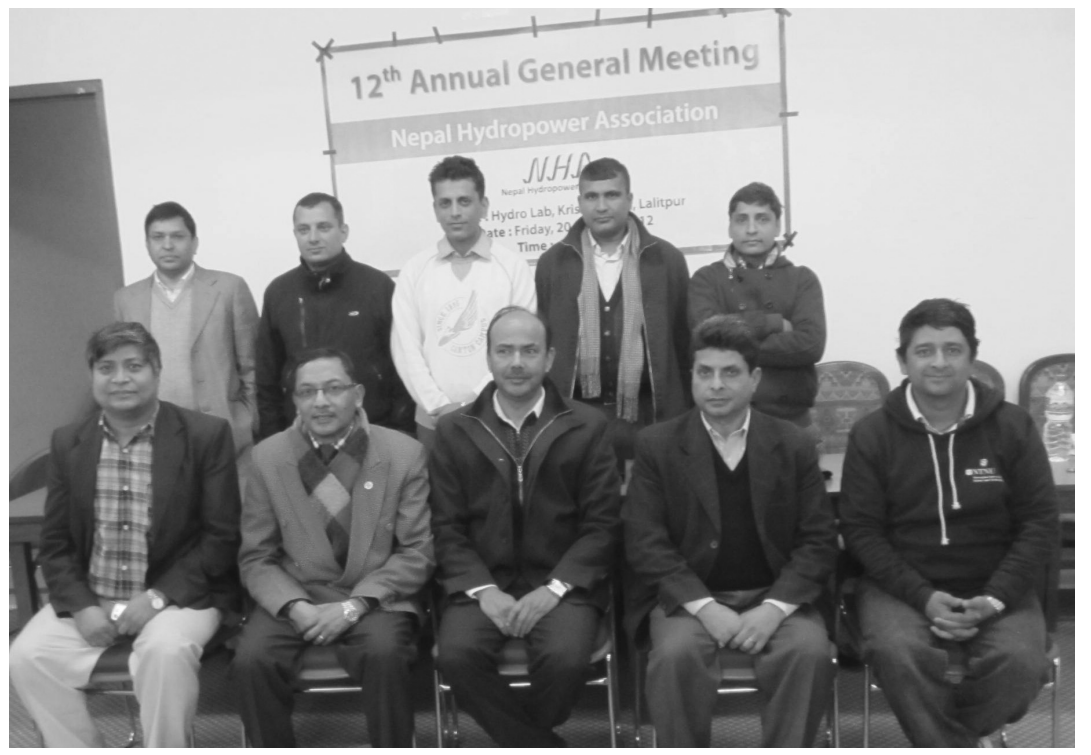

